Volume 11|Issue3

September 2020

\title{
Applying Lessons from the U.S. Indian Child Welfare Act to Recently Passed Federal Child Protection Legislation in Canada
}

Hayley Hahn

University of Virginia School of Law, United States, hah4gn@virginia.edu

Johanna Caldwell

McGill University, Centre for Research on Children \& Families, Canada, johanna.caldwell@mail.mcgill.ca

Vandna Sinha

University of Colorado (Boulder) School of Education, United States, Vandna.Sinha@Colorado.edu

Recommended Citation

Hahn, H., Caldwell, J., \& Sinha, V. (2020). Applying lessons from the U.S. Indian Child Welfare Act to recently passed federal child protection legislation in Canada. The International Indigenous Policy Journal, 11(3). https://10.18584/iipj.2020.11.3.8206 


\title{
Applying Lessons from the U.S. Indian Child Welfare Act to Recently Passed Federal Child Protection Legislation in Canada
}

\begin{abstract}
Indigenous children are overrepresented in child protection systems in the United States and to an even greater degree in Canada. Canada has recently passed federal child welfare legislation, Bill C-92, with the goal of affirming the rights of Indigenous Peoples and establishing guidelines with respect to child and family services for Indigenous children. The aim of this article is to contribute to ongoing discussions about the recently passed Canadian legislation, drawing on lessons learned in the United States context. The Indian Child Welfare Act (ICWA), passed in the United States in 1978, has created a legislative paradigm, which in some cases has been bolstered by statelevel provisions. The ICWA can provide helpful lessons to consider in Canada as the new legislation is implemented and amended over time. Specifically, we examine elements of the ICWA related to accessibility and compliance with the law, along with deeper analysis of state-level statutes related to adoption provisions in light of the phenomenon of transracial adoption of Indigenous children. As reactions to the Canadian federal law have been mixed, this policy analysis may be supportive of conversations regarding its further development, particularly related to funding and enforcement. On a broader level, considerations of Indigenous community jurisdiction over child and family policies within our discussion are relevant to various settler-colonial contexts.
\end{abstract}

\section{Keywords}

American Indian, Native American, Indigenous Peoples, Canada, United States, child welfare, child protection, Indian Child Welfare Act (ICWA), cultural continuity

\section{Creative Commons License} (c) (1) (9)

This work is licensed under a Creative Commons Attribution-Noncommercial-No Derivative Works 4.0License. 


\section{Applying Lessons from the U.S. Indian Child Welfare Act to Recently Passed Federal Child Protection Legislation in Canada}

In June of 2019, the Canadian federal government passed Bill C-92, An Act Respecting First Nations, Inuit and Métis Children, Youth and Families. The Bill included principles of "cultural continuity" and defined the best interests of children according to not only physical, emotional, and psychological safety, but cultural and linguistic ties as well (Bill C-92, 2019). The Act partially responds to recent public testimony regarding the significant impacts of colonization on Indigenous ${ }^{1}$ communities in Canada. This testimony and related advocacy efforts have resulted in calls for reconciliation, or a "coming to terms with events of the past in a manner that overcomes conflict and establishes a respectful and healthy relationship among people going forward" (Truth and Reconciliation Commission of Canada [TRC], 2015b, p. 3).

Reactions to this new Canadian federal legislation have been mixed. While some groups, such as the Assembly of First Nations, have argued that the Bill will strengthen Indigenous families (Assembly of First Nations, 2019), others have been critical of the legislation citing concerns about it not prioritizing Indigenous communities' self-determination ("First Nations Chiefs Call for Protests," 2019). Additional concerns raised by some First Nations include the delegation of funding to the provinces and "a perceived lack of consultation by the federal government during its drafting” (Isaac, 2019, para. 5). Prominent First Nations children's advocate Dr. Cindy Blackstock noted that the Bill "offers Indigenous children a colonial Faustian bargain: Accept the flawed bill in its current state or get nothing" (Metallic, Friedland, \& Morales, 2019, p. 4). In its present form, Bill C-92 fails to provide mechanisms to fully realize the aims of reconciliation or remediation, particularly regarding Indigenous self-determination in child protection proceedings.

Prior to the Bill's introduction, the former Indigenous Services Minister Jane Philpott announced a sixpart plan to improve First Nations child welfare in Canada, raising the possibility of developing federal Indigenous child welfare legislation (Tasker, 2018). In doing so, she referred to the relative success of the U.S. federal Indian Child Welfare Act (ICWA, 1978). Similarly, advocates and academics calling for federal Indigenous child welfare legislation in Canada have also cited the ICWA (see for example Grammond, 2018). Bill C-92 presents a more modest proposal than the ICWA. While both federal laws attempt to improve outcomes for Indigenous families regarding child protection involvement, the new Canadian federal legislation is distinct from the longstanding U.S. federal law both in the way it treats Indigenous communities' sovereignty in child protection decisions and the judicial context in which these decisions are made.

In this article, we examine the ICWA to identify lessons that may be relevant in the Canadian context today. We focus primarily on the relevance of the ICWA to federal legislation in Canada. Through analyzing the ICWA's history and implementation in the United States, we underscore the value of federal Indigenous child welfare legislation, while emphasizing the key provisions that may prove most useful in the Canadian context. We also examine lessons from the United States regarding the

\footnotetext{
${ }^{1}$ Many different terms, including Aboriginal, Indian, Native, and Indigenous, are used to refer to the Indigenous Peoples of North America. In this article, when discussing a particular piece of legislation, the terminology mirrors the language of the law. When no term is specified, Indigenous is used in this article.
} 
coordination of state and federal Indigenous child welfare legislation in order to provide a nuanced analysis that might be applicable to the relationship between provincial and territorial jurisdictions in Indigenous child welfare in Canada. We focus on the adoption protections for Indigenous children passed by state governments in order to highlight the potential benefits and challenges of implementing Indigenous child welfare legislation at multiple levels of government. To provide background for this analysis, we draw on work that centres the voices of Indigenous individuals adopted as children into non-Indigenous families. Testimony of these transracial Indigenous adoptees demonstrates the need for legislation that provides Indigenous children with access to their extended families, communities, and cultures.

After analyzing federal- and state-level Indigenous child welfare provisions in the United States context, we discuss the ICWA in relation to the federal legislation recently passed in Canada and earlier proposals for federal Indigenous child welfare legislation advanced by scholars, attorneys, and activists in the Canadian context. We examine the applicability of the ICWA to the new Canadian legislation, and highlight the key lessons emerging from our analysis of ICWA implementation that seem relevant to the Canadian context. While the newly introduced Canadian legislation is a good first step, ongoing revision of the legislative framework will be necessary. The intent of this article is to contribute to discussions of how this federal legislation in Canada could be further bolstered in order to support and formally protect self-determination in child welfare by Indigenous communities.

\section{Background}

\section{Residential and Boarding Schools in the U.S. and Canada}

Throughout the late nineteenth and twentieth centuries, government officials from both the United States and Canada forced Indigenous children to attend boarding or residential schools, institutions that functioned as sites of forcible assimilation (National Council of Juvenile and Family Court Judges, 2012; Task Force on Federal, State, and Tribal Jurisdiction, 1976; TRC, 2015a). The schools were part of a broader regime of U.S. and Canadian settler colonial practices and policies that fractured Indigenous communities by destroying the traditional economies and governance, and restricted Indigenous Peoples to reserves with inadequate access to Traditional Land and poor sanitation and shelter (TRC, 2015a).

The residential schools aimed to eradicate Indigenous Peoples and cultures through cultural genocide, "the destruction of those structures and practices that allow the group to continue as a group," by fully assimilating Indigenous Peoples into mainstream, White, Anglo-Canadian culture (TRC, 2015a, p. 1). Teachers and administrators in these schools facilitated the process of cultural genocide by preventing Indigenous children from speaking their languages, practicing their religions, or contacting their families; many Indigenous children were physically or sexually abused and neglected in the schools (National Council of Juvenile and Family Court Judges, 2012; TRC, 2015a). The residential schools were also inadequately funded, leading to malnutrition, poor student supervision, and high rates of student illness and death (National Council of Juvenile and Family Court Judges, 2012; TRC, 2015a). Documents and testimony from the time show that school administrators and government officials were aware of poor conditions of the institutions, including student deaths (Bryce, 1907; Task Force on Federal, State, and Tribal Jurisdiction, 1976; TRC, 2015a). 
In response to these inhumane conditions, many Indigenous people and communities resisted the residential schools (Milloy, 1999; Subcommittee on Indian Affairs, 1974; TRC, 2015a). As a result of Indigenous resistance and advocacy efforts, the Canadian and U.S. governments began closing the schools after the Second World War, but some remained in operation until the late twentieth century (Milloy, 1999; Subcommittee on Indian Affairs, 1974).

\section{The Sixties Scoop and the Era of Child Welfare}

As residential schools were closing from the 1950s to the 1980s, child welfare workers began to apprehend Indigenous children at disproportionately high rates, placing the vast majority of these children in non-Indigenous foster and adoptive homes (Johnston, 1983; National Council of Juvenile and Family Court Judges, 2012; Nichols, 2017; Task Force on Federal, State, and Tribal Jurisdiction, 1976). This period of time is referred to in Canada as the "Sixties Scoop," a name coined after an employee of the Ministry of Human Resources in British Columbia regretfully "admitted that provincial social workers would, quite literally, scoop children from reserves on the slightest pretext” (Johnston, 1983, p. 23).

A parallel mass removal of Indigenous children by child welfare authorities in the United States took place during the same time period (Johnston, 1983). United States Senate hearings on Indigenous child welfare held in 1974 demonstrated that many social service agents and agencies were deeply biased against Indigenous people, prompting agencies to "literally stea[1] children," and that the vast majority of Indian children taken from their families were removed on the basis of neglect, rather than physical abuse (Subcommittee on Indian Affairs, 1974, pp. 2, 4).

Indigenous children adopted and raised by non-Indigenous families in the 1950s and 1960s have emphasized the adverse effects of growing up separated from their Indigenous communities and cultures (Carrière, 2010; Simon \& Hernandez, 2008). For example, interviews with 20 Native American transracial adoptees in the United States revealed that, although 55\% believed that it was better for White or non-Indigenous families to adopt an Indigenous child than for the child to languish in residential facilities, 95\% expressed a desire for Indigenous children to remain connected to their culture, and the majority expressed that adoption placement with other Indigenous families best served this purpose (Simon \& Hernandez, 2008). Likewise, Carrière (2008) conducted interviews with 18 Indigenous transracial adult adoptees and found that "each adoptee experienced loss in several areas of her or his life" (p. 64). In subsequent writing on Indigenous children and adoption, she emphasized the need for building and maintaining an Indigenous child's connection to her or his Indigenous community and culture in order to foster resiliency and positive identity formation (Carrière, 2010). Difficulties related to being disconnected from Indigenous culture - such as difficulties related to identity formation and racism - can lead to challenges later on in life (Sinclair, 2009). In a literature review and series of interviews with adult transracial Indigenous adoptees, Sinclair (2007) found adults expressed that contact with their immediate and extended birth family "might have helped alleviate the sense of difference and cultural isolation" that they experienced throughout their lives (p. 77).

Additionally, research suggests that many Indigenous transracial adoptions breakdown for these same reasons. One study analyzed the outcomes for 37 families in Canada who adopted Indigenous children, finding that almost half of these adoptions broke down by the time the child was 15 years old (Bagley, 
The International Indigenous Policy Journal Vol. 11, Iss. 3

1991). Available evidence suggests that providing Indigenous children in care with culturally safe permanent placements is paramount not just for their wellbeing as children, but for their transition into adolescence and health in adulthood (di Tomasso \& de Finney, 2015; Sinclair, 2009).

\section{Overrepresentation of Indigenous Children in Child Welfare}

Indigenous children continue to be overrepresented in child welfare systems in both Canada (Sinha et al., 2011; Trocmé et al., 2010) and the United States (National Council of Juvenile and Family Court Judges, 2017; National Indian Child Welfare Association, 2017). Data from the Canadian 2016 National Household Survey indicated that Indigenous children aged 0 to 14 are placed in care at 13 times the rate of non-Indigenous children (Statistics Canada, 2016). A more detailed analysis of data from 2011 indicated that Indigenous children in Canada face disproportionate rates of placement in foster care: Although Aboriginal children make up less than $10 \%$ of Canada's population of children aged 0 to 15 , they comprise nearly half of the total foster child population (Sinha \& Wray, 2015). More specifically, First Nations, Métis, and Inuit children were placed in foster care at 15.3, 5.8, and 9.6 times the rate of non-Indigenous children, respectively (Sinha \& Wray, 2015). The overrepresentation of Indigenous children in care is driven primarily by cases involving neglect. Results from the 2008 First Nations Child Incidence Study revealed that neglect investigations were substantiated at a rate 8 times higher for First Nations children than for non-Indigenous children (Sinha et al., 2011).

Indigenous children are also overrepresented in the child welfare system in the United States, although at a significantly lower rate than in Canada. The rate of American Indian and Alaska Native children who experience foster care is 2.6 times higher than the rate of foster care and adoption for the general child population (National Council of Juvenile and Family Court Judges, 2017). The lower level of Indigenous overrepresentation in the U.S. compared to Canada may to a certain extent reflect the 1978 enactment of the federal ICWA, which was explicitly intended to curb the rate of Indigenous child apprehension. Though issues with accessibility, compliance, and funding hamper the complete realization of goals articulated in the ICWA, the Act still marks a significant advancement in Indigenous child welfare in the U.S., as it provides a tool for addressing the continued disproportionate placement of Indigenous children in care (Casey Family Programs, 2015; Kern, 2009; National Indian Child Welfare Association, 2015; Watt \& Kim, 2019).

Similarities across the U.S. and Canada suggest that lessons from the ICWA may be relevant in the Canadian context. Indeed, the ICWA supports Indigenous communities' sovereignty over their children, and by extension may be a mechanism of decolonizing child welfare (Jaffke, 2006). However, important distinctions between the two are needed to situate our analysis. Though Bill C-92 and the ICWA share a similar purpose, differences in scope and procedural and substantive provisions distinguish the ICWA as a more ambitious and comprehensive piece of legislation. Analyzing the successes and shortcomings of the ICWA and understanding how this federal legislation operates alongside state forms of Indigenous child welfare protection statutes in the U.S. may help to advance ongoing discussions regarding Indigenous child welfare policy in Canada. 


\section{Analysis}

\section{History of the ICWA's Enactment}

Following World War II, as federal boarding schools began closing, Indigenous children in the United States faced high rates of apprehension and transracial adoption (Graham, 2008). Indigenous Peoples continually resisted the removal of their children. For example, in the 1960s, parents from the Devils Lake Sioux Reservation — now called the Spirit Lake Sioux — traveled to the Bureau of Indian Affairs in Washington, D.C., as part of an effort to prevent child welfare workers from apprehending their children (Subcommittee on Indian Affairs, 1974, p. 38). The advocacy efforts of these and other Indigenous Peoples forced the United States Congress to address the disproportionate apprehension of Indigenous children (Subcommittee on Indian Affairs, 1974). In 1974, the U.S. Senate, led by Indian Affairs Subcommittee Chairman Senator James Abourezk of South Dakota, held hearings to address the decades-long forcible removal of Indigenous children from their families (Subcommittee on Indian Affairs,1974). Through the hearings, the Subcommittee sought to acknowledge the deleterious effects of the Indian boarding school system, as well as address the alarmingly high rate at which social services removed Indigenous children from their homes and placed them with non-Indigenous families (Subcommittee on Indian Affairs, 1974).

Following the Senate hearings, the United States Congress commissioned a task force to examine jurisdictional issues arising from the relationships between federal, state, and tribal authorities. In 1976, this task force released its findings in the Report on Federal, State, and Tribal Jurisdiction, which analyzed the ways in which existing legislation hampered the safety and prosperity of tribal communities (Task Force on Federal, State, and Tribal Jurisdiction, 1976). In particular, the Report detailed the ways in which Public Law 280 (PL-280, 1953) worked "to end the unique relationship that existed between the Federal Government and tribal governments since the formation of the Federal Government" through empowering states to exercise jurisdiction over vast categories of criminal and civil cases in Indigenous communities, including child welfare cases (Task Force on Federal, State and Tribal Jurisdiction, 1976, p. 4). ${ }^{2}$

The Report found that Indian children were being placed in care "at rates far out of proportion to their percentage population” (Task Force on Federal, State, and Tribal Jurisdiction, 1976, p. 179).

Furthermore, the Task Force found that state oversight of Indian child welfare directly contributed to the disproportionate placement of Indian children in care. The Task Force identified the tribes' lack of standing in court cases involving Indian children as a major impediment to the preservation of Indian families and communities. In response to these observations, the Task Force urged the United States government "to do all within its power to ensure Indian children remain in Indian homes" (Task Force on Federal, State, and Tribal Jurisdiction, 1976, p. 87).

\footnotetext{
${ }^{2}$ To note, Public Law 280 only applies in select states, specifically Alaska, California, Minnesota, Nebraska, Oregon, and Wisconsin ("mandatory PL-280" states), and some reservations in Florida, Idaho, and Washington ("optional PL-280" jurisdictions; The United States Attorney's Office District of Minnesota, 2015).
}

Published by Scholarship@Western, 2020 


\section{The Passage and Successes of the ICWA}

In 1978, the U.S. Congress heeded the Task Force's call to action by passing the Indian Child Welfare Act (the ICWA). This federal legislation stated, "there is no resource that is more vital to the continued existence and integrity of Indian tribes than their children” (ICWA, 1978, \$ 1901(3)). Recognized by many national child advocacy organizations as the "gold standard" of Indigenous child welfare, the ICWA was designed to prevent the breakup of Indigenous families and communities (National Indian Child Welfare Association, 2015). In the United States, tribes never formally ceded their jurisdiction over child welfare to the federal or state governments. Partly in recognition of this reality, the ICWA (1978) does the following:

- Affirms tribes' jurisdiction over Indian child custody proceedings ( $\$ \$ 1911-2,1918$ );

- Affirms that Indian children who live on a reservation are under the exclusive jurisdiction of the tribal court for that reservation ( $\$ 1911$; see also Bureau of Indian Affairs, 2016b; Jones et al., 2008);

- Grants tribes standing in foster care proceedings, termination of parental rights proceedings, pre-adoptive placement, and adoption proceedings involving Indian children ( $\$ 1903)$;

- Defines Indian child status ( $\$ 1903)$;

- Provides recourse for Indian tribes and parents in cases where a child subject to ICWA's protections is improperly removed ( $\$ S 1914,1920)$;

- Outlines placement for Indian children in care, emphasizing that the court must prioritize, whenever possible, the placement preferences of Indian families and tribes $(\$ 1915)$;

- Enshrines active efforts - a higher standard than the reasonable efforts typically required by child welfare legislation - "to provide remedial services and rehabilitative programs designed to prevent the breakup of the Indian family and that these efforts have proved unsuccessful” ( $\$ 1912)$;

- Provides for the testimony of "qualified expert witnesses" in determining foster care placement orders and parental rights termination orders ( $\$ S 1912 \mathrm{e}-\mathrm{f}$ );

- Provides funding schemes for social services for Indian children living on- and offreservation ( $\$ \$ 1931-3)$;

- Contains other provisions aimed at safeguarding Indian children's access to their families and tribes ( $\$ \$ 1913,1916,1919,1934,1951-1952)$; and

- Ensures that tribes must be contacted when parental rights are potentially terminated in cases of both voluntary and involuntary adoptions ( $\$ 1912$; see also Jones et al., 2008).

Taken together, these elements of the ICWA are intended to support the preservation of Indigenous ways of life and to function as a mechanism to support Indigenous communities in asserting their inherent sovereignty over their children. In practical terms, the U.S. law provides Indigenous families and communities with a mandate and a tool for contesting the unwarranted removal of their children.

Though the elements of the ICWA itself have remained consistent over time, the context of, complements to, and interpretation of the ICWA have changed over the years. U.S. federal legislation impacting the child welfare landscape has expanded, affecting administration and regulation of local child welfare proceedings (Child Welfare Information Gateway, 2019). Legislation such as the Adoption 
and Safe Families Act (1997) and the Multiethnic Placement Act (MEPA, 1994 amended 1996) have posed challenges to ICWA implementation. More recently, the Fostering Connections to Success and Increasing Adoptions Act (2008) and the Family First Prevention and Services Act (2018) have moved child welfare policies in directions that are more supportive of ICWA implementation. These shifts in the federal legislative and regulatory landscape have implications for states, which administrate child welfare systems in the U.S.

The jurisprudential landscape also shapes the context in which the ICWA is implemented. Though there have been many cases heard by lower courts, as of 2019, the United States Supreme Court has only heard two ICWA cases: Mississippi Band of Choctaw Indians v. Holyfield (1989) and Adoptive Couple v. Baby Girl (2013). ${ }^{3}$ The Court did not overturn ICWA in either case. However, partially in response to the backlash from Adoptive Couple v. Baby Girl (see for example Trowbridge, 2017), the federal government began the process of developing clearer federal guidelines for ICWA, culminating in the adoption of new 2016 Guidelines for Implementing the Indian Child Welfare Act and 2016 Bureau of Indian Affairs Final Rule, 25 CFR Part 23 (Bureau of Indian Affairs, 2016a, 2016b). The new guidelines are binding as federal regulation, replacing a 2015 version, which was not binding.

The revised ICWA guidelines emphasized that in every child custody proceeding, agencies must determine whether the ICWA applies (Bureau of Indian Affairs, 2016a). Additionally, the 2016 guidelines clarified the procedures for notifying relevant parties, such as an Indigenous child's tribe and parents, regarding child custody proceedings (Bureau of Indian Affairs, 2016a). Moreover, in emphasizing other provisions that recognize tribal sovereignty, such as the right to petition for a transfer of child custody proceedings to a tribal court, the 2016 guidelines articulate the importance of the wellbeing of Indigenous children while recognizing the inherent sovereignty and self-determination of tribes (Bureau of Indian Affairs, 2016a). These guidelines reinforced the ways in which federal settlercolonial governments could support reconciliation efforts through recognizing Indigenous communities' right to keep their children, as well as safeguarding Indigenous children's connections with their families, communities, and cultures.

\section{Ongoing Indigenous Child Welfare Concerns: Accessibility and Compliance}

Implementation of the ICWA has faced challenges related to accessibility and compliance due to the interrelated factors of funding, awareness and knowledge of the law, and enforceability. At the most basic level, accurate and timely identification of children to whom the ICWA applies presents a major obstacle to ICWA's successful implementation. Existing research demonstrates that child welfare workers have great difficulty identifying Indigenous children (Fluke et al., 2011). The current presidential administration recently proposed to delay implementation of federal regulations that might motivate child welfare systems to improve identification by requiring states to track and report Indian children and ICWA cases (RIN: 0970-AC72 Adoption and Foster Care Analysis and Reporting System: Advance Notice of Proposed Rulemaking; Children and Families Administration, 2018).

\footnotetext{
${ }^{3}$ Thousands of ICWA cases have been advanced in state courts since the statute's adoption; however, the paucity of ICWA cases heard by the United States Supreme Court is consistent with the Court's "traditional preference that state law and state courts handle family law matters" (Halibi, 2014, p. 144). 
The International Indigenous Policy Journal Vol. 11, Iss. 3

Access to protections for Indigenous children and communities may also be limited by the ways in which ICWA is interpreted in legal proceedings. For example, some scholars have argued that reliance on the "Existing Indian Family (EIF) exception" has the potential to threaten the broad application of ICWA (Sandefur, 2017; Zug, 2014). The EIF exception is a legal argument wherein the ICWA is interpreted as applying only in cases involving a child "removed from an 'existing Indian family unit' or 'Indian home or culture"' (Jaffke, 2006, pp. 741-742). Under this interpretation, ICWA would not apply in cases involving an Indigenous child who never lived within an Indigenous family unit - for instance, if the child was apprehended at birth or if the court finds that the child's Indigenous family had inadequate ties to an Indigenous community or culture (Jaffke, 2006; see also Baby Boy C. v. Tohono O'odham Nation, 2005). Moreover, the determination of whether a child's Indigenous family has adequate ties to an Indigenous community or culture would rest with state or federal court judges rather than Indigenous authorities (Jaffke, 2006). Though the EIF remains prominent in existing literature about ICWA, it has rarely been used in jurisdictions with significant Indian populations, and judicial decisions over the past several decades indicate decreased reliance on the EIF exception (Wilson, 2007). The EIF does not figure prominently in state court proceedings and where state courts have referred to the EIF, the outcomes directly contravene the 2016 federal guidelines (Bureau of Indian Affairs, 2016a).

Compliance with the ICWA is also compromised by a lack of funding for its implementation (Wahl, 2010). Awareness of the law on the part of judges and attorneys is limited due to insufficient federal funds dedicated to ICWA education across jurisdictions (Fort, 2010). Across the country, child welfare and advocacy groups, along with some state legal organizations, are allocating their own funding to improve ICWA awareness and implementation (Casey Family Programs, 2015). For example, to address these issues, some state legal organizations such as the Michigan State Court Administrative Office have devoted funds to educating attorneys on ICWA's requirements (Fort, 2012). While these initiatives speak to the potential of states and other legal and social bodies to promote ICWA implementation and compliance, they are ad hoc endeavours whose longevity is tenuous due to a lack of federal mandate and funding for awareness of ICWA provisions.

More specifically, implementation of the ICWA is complicated by a lack of resources for tribal implementation of the law (ICWA Compliance Task Force, 2017). This problem is particularly detrimental to ICWA compliance in states such as California, where many Indigenous people come from tribes located outside of the state (ICWA Compliance Task Force, 2017). Although tribes can apply for some funding under Title IV-E of the Social Security Act, this funding is limited and sharing funds is complicated (ICWA Compliance Task Force, 2017; see also Government Accountability Office, 2005; Bureau of Indian Affairs, 2016a). Indeed, though tribes receive federal funds for the provision of social services on reservation, these funds are not ICWA-specific and thus remote and rural tribes may lack the designated funds to fully support the ICWA (Children's Bureau, 2009; National Child Welfare Resource Center for Tribes, 2014).

Further, there is currently no designated federal agency with the explicit mandate of monitoring state compliance with the ICWA (Casey Family Programs, 2015). Moreover, although the revised federal guidelines help to clarify ICWA standards, general child welfare standards vary across states, so ensuring standardized application of ICWA is challenging (Casey Family Programs, 2015). The absence of federal oversight has also meant a lack of guidance for state jurisdictions regarding implementation of and compliance with the ICWA (Kern, 2009). Although the 2015 federal guidelines provided some 
Hahn et al.: Applying Lessons from the U.S. Indian Child Welfare Act

clarification regarding federal ICWA standards, instituting a single federal agency to monitor ICWA compliance would likely improve ICWA enforcement (Indian Affairs Bureau, 2015).

\section{State-Level ICWA Provisions}

State-level child welfare legislation in the U.S. is implemented in tandem with federal provisions, including the ICWA and other federal statutes, which determine some nationwide child welfare regulations and protections. As of 2019, 33 U.S. states had passed some form of child welfare legislation designed to protect Indigenous children. In some cases, these protections serve to explicitly reinforce the federal ICWA provisions. Many of these state-level protections were passed to address the persistently high rate at which Indigenous children in some states are placed in out of home care (National Council of Juvenile and Family Court Judges, 2017).

Critically, as reflected in Tables 1 and 2, eight states - Washington, Minnesota, Michigan, Wisconsin, California, Nebraska, Oklahoma, and Iowa-provide for state forms of the ICWA, which explicitly reinforce provisions of the federal law (Turtle Talk, 2015). The 2015 guidelines developed by the federal government took a great deal from these and other state-level forms of ICWA. Thus, the development of the 2015 guidelines and subsequent 2016 guidelines and Bureau of Indian Affairs final ruling reflect the potential benefits of allowing state or provincial governments to serve as policy laboratories for the federal government.

Tables 1 and 2 build on a list of state-level ICWA provisions produced by the National Conference of State Legislatures' (NCSL, 2018) State Statutes Related to the Indian Child Welfare Act. The NCSL lists statutes broadly related to ICWA, but consideration of this full range of statutes is beyond the scope of this article. We focus on adoption protections in order to illustrate the breadth of state protections in the context of one form of child placement. In the tables below, we have identified provisions pertaining specifically to adoption and grouped them thematically. Our intent is for these tables to provide an example of some of the ways in which state laws may augment federal Indigenous child welfare legislation by providing clarity and additional mechanisms for implementation and enforcement. Granular analysis of state statutes with attention to non-adoption forms of placement (e.g., kinship or foster care), in addition to other child protection practice domains (e.g., family preservation, risk assessment, etc.), would further illustrate the ways in which these issues are dealt with at various jurisdictional levels in the U.S.

Table 1 shows state-level ICWA provisions, indicating the following: (a) Name(s) and sections of state statute with provisions for Indian children: This column identifies the names and numerical designations of state statutes containing adoption provisions for Indian children. (b) State versions of ICWA and Indian Family Preservation Acts: As of 2019, eight states have passed their own versions of ICWA and Indian Family Preservation Acts. In California, these provisions are incorporated into the state's Family Code. (c) Citation of federal ICWA: Indicates whether the state statutes cite the ICWA. (d) Recognition of tribal authority: These forms of recognition include the responsibility to contact or consult with the Indian child's tribe, recognition of tribal jurisdiction, right of the tribe to intervene in or be party to proceedings, and protection against the Existing Indian Family ("EIF”) defence. 
The International Indigenous Policy Journal Vol. 11, Iss. 3

Table 1. State-Level ICWA Provisions

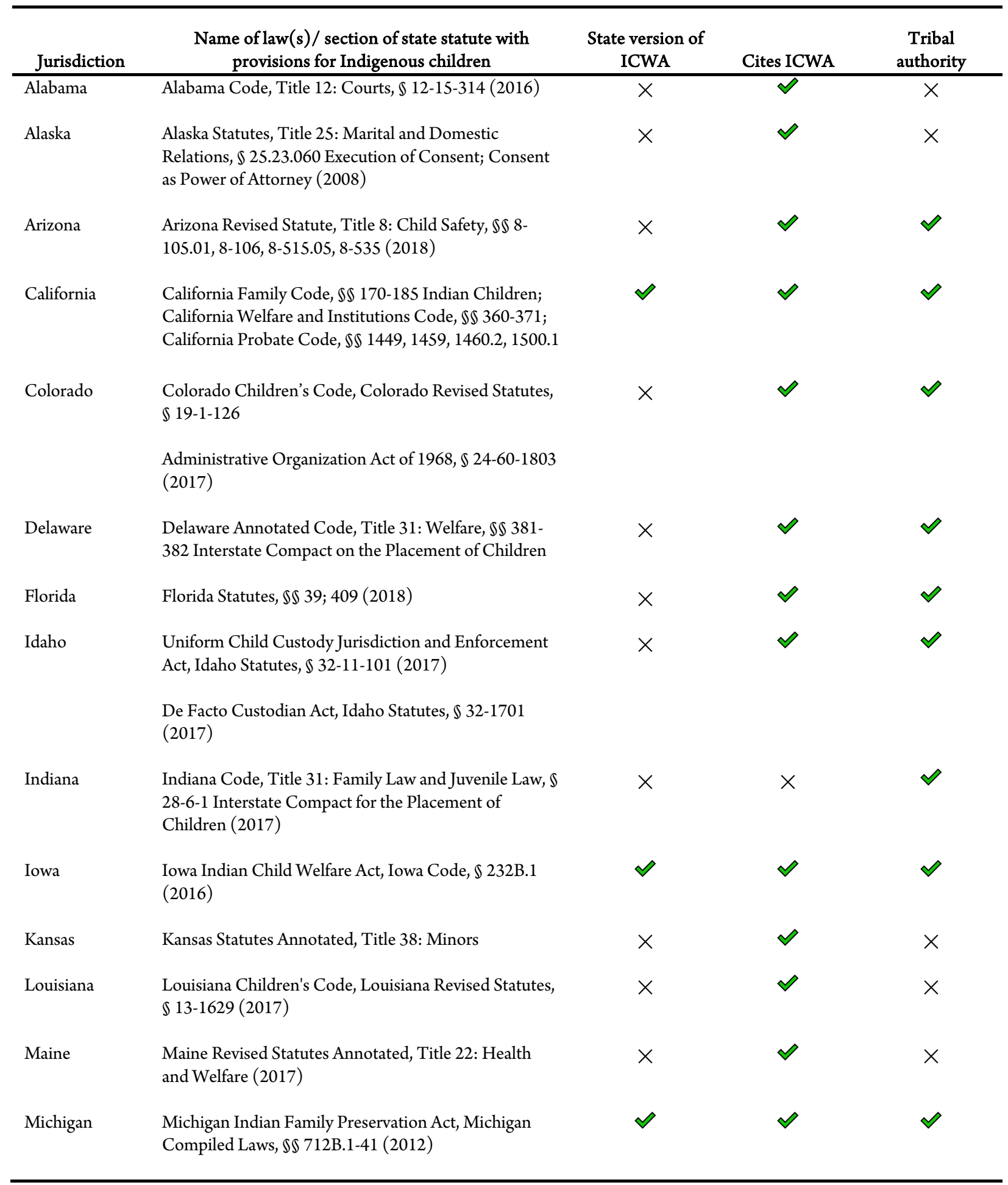


Table 1. State-Level ICWA Provisions (continued)

\begin{tabular}{|c|c|c|c|c|}
\hline Jurisdiction & $\begin{array}{c}\text { Name of law }(s) / \text { section of state statute with } \\
\text { provisions for Indigenous children }\end{array}$ & $\begin{array}{l}\text { State version of } \\
\text { ICWA }\end{array}$ & Cites ICWA & Tribal authority \\
\hline Minnesota & $\begin{array}{l}\text { Minnesota Statutes, } \$ 256.01 \text { Commissioner of } \\
\text { Human Services, Powers, Duties; } \$ 257 C \text { De Factor } \\
\text { Custodian and Interested Third Party; } \$ 259 \text { Change } \\
\text { of Name, Adoption; } \$ 260.012 \text { Duty to Ensure } \\
\text { Placement Prevention and Family Reunification, } \\
\text { Reasonable Efforts; } \$ \$ 260.851-260.92 \text { Minnesota } \\
\text { Interstate Compact on the Placement of Children } \\
\text { (2017) } \\
\text { Minnesota Indian Family Preservation Act, Minnesota } \\
\text { Statutes, } \$ \$ 260.751-260.835 \text { (2017) }\end{array}$ & $\mathscr{V}$ & $\mathscr{V}$ & $\checkmark$ \\
\hline Mississippi & $\begin{array}{l}\text { Uniform Child Custody Jurisdiction and Enforcement } \\
\text { Act, Mississippi Code Annotated, } \$ 93-27-104 \\
\text { Application to Indian Tribes (2010) }\end{array}$ & $\times$ & $\mathscr{V}$ & $\mathscr{V}$ \\
\hline Missouri & $\begin{array}{l}\text { Uniform Child Custody Jurisdiction and Enforcement } \\
\text { Act, Missouri Revised Statutes, } ₫ 452.715 \text { Application } \\
\text { to Indian Tribes (2009) }\end{array}$ & $\times$ & $\mathscr{q}$ & $\mathscr{V}$ \\
\hline Montana & $\begin{array}{l}\text { Montana Safe Haven Newborn Protection Act, } \\
\text { Montana Code Annotated, } \$ \text { 40-6-405 (2019) } \\
\text { Montana Code Annotated, Title 41: Minors, Chapter } \\
\text { 3: Child Abuse and Neglect; Title 42: Adoption, } \\
\text { Chapter 2: Adoption of Child, Part 6: Petition to } \\
\text { Terminate Parental Rights } \ 42-2-604 \text {; Title 42: } \\
\text { Adoption, Chapter 4: Placements for Adoption } ₫ 42-4 \text {; } \\
\text { Title 52: Family Services, Chapter 2: Children’s } \\
\text { Services, Part 1: Child Welfare Services, } \$ 52-2-117 \\
\text { Indian Child Welfare Specialist (2019) }\end{array}$ & $x$ & $\mathscr{V}$ & $\mathscr{V}$ \\
\hline Nebraska & $\begin{array}{l}\text { Nebraska Indian Child Welfare Act, Nebraska Revised } \\
\text { Statutes, } \$ \$ 43-1501 \text { to } 1517 \text { (2015) } \\
\text { Nebraska Statutes, } \$ 43-1103 \text { Interstate Compact for } \\
\text { the Placement of Children }\end{array}$ & $\mathscr{V}$ & $\mathscr{V}$ & $\mathscr{V}$ \\
\hline
\end{tabular}


Table 1. State-Level ICWA Provisions (continued)

\begin{tabular}{|c|c|c|c|c|}
\hline Jurisdiction & $\begin{array}{c}\text { Name of law }(\mathrm{s}) / \text { section of state statute with } \\
\text { provisions for Indigenous children }\end{array}$ & $\begin{array}{l}\text { State version of } \\
\text { ICWA }\end{array}$ & Cites ICWA & Tribal authority \\
\hline \multirow[t]{4}{*}{ New Mexico } & $\begin{array}{l}\text { Safe Haven for Infants Act, New Mexico Statutes, } \\
\$ 24-22(2018)\end{array}$ & $x$ & $\mathscr{V}$ & $\mathscr{V}$ \\
\hline & $\begin{array}{l}\text { Children's Code, New Mexico Statutes, } \$ \$ 32 \mathrm{~A}-1- \\
8,32 \mathrm{~A}-1-14(2018)\end{array}$ & & & \\
\hline & $\begin{array}{l}\text { Adoption Act, New Mexico Statutes, } \$ 32 A-5 \\
(2018)\end{array}$ & & & \\
\hline & $\begin{array}{l}\text { Kinship Guardianship Act, New Mexico Statutes, } \\
\$ 40-10 B(2018)\end{array}$ & & & \\
\hline Nevada & $\begin{array}{l}\text { Nevada Revised Statutes, Protection of Children } \\
\text { from Abuse and Neglect, } \$ 432 \text { B.397 (2015) }\end{array}$ & $x$ & $\mathscr{V}$ & $x$ \\
\hline North Carolina & $\begin{array}{l}\text { North Carolina General Statutes, } \$ 48 \text { Adoptions } \\
(2017)\end{array}$ & $x$ & $\mathscr{N}$ & $x$ \\
\hline \multirow[t]{2}{*}{ North Dakota } & $\begin{array}{l}\text { Uniform Child Custody Jurisdiction and } \\
\text { Enforcement Act, North Dakota Century Code, } \\
\mathbb{\$} 14-14.1 \text { (2017) }\end{array}$ & $x$ & $\mathscr{N}$ & $x$ \\
\hline & $\begin{array}{l}\text { Uniform Juvenile Court Act, North Dakota } \\
\text { Century Code } \$ 27-20\end{array}$ & & & \\
\hline Oklahoma & $\begin{array}{l}\text { Oklahoma Indian Child Welfare Act, Oklahoma } \\
\text { Statute, } \$ \$ \text { 40.1-40.9 (2017) }\end{array}$ & $\mathscr{V}$ & $\mathscr{V}$ & $\mathscr{V}$ \\
\hline Oregon & $\begin{array}{l}\text { Oregon Revised Statutes, } \$ \$ 109.309,312,350 \\
\text { Adoption-petition, consent, decree; } \$ 125.025 \\
\text { Protective Proceedings-court authority; } \$ \\
418.627 \text { Child Welfare Services-placement } \\
\text { consistent with ICWA; } \$ \$ 419 A, 419 B \text { Juvenile } \\
\text { Code }\end{array}$ & $x$ & $\mathscr{V}$ & $\mathscr{V}$ \\
\hline South Carolina & $\begin{array}{l}\text { Catawba Indian Claims Settlement Act, South } \\
\text { Carolina Code of Laws Annotated, } \$ 27-16-80\end{array}$ & $x$ & $\mathscr{V}$ & $x$ \\
\hline South Dakota & $\begin{array}{l}\text { South Dakota Codified Laws Annotated, } \$ \$ 25- \\
\text { 5A Voluntary Termination of Parental Relation; } \\
\text { 26-7A Juvenile Court; 26-8A Protection of } \\
\text { Children from Abuse and Neglect (2018) }\end{array}$ & $x$ & $\mathscr{V}$ & $\mathscr{V}$ \\
\hline Tennessee & $\begin{array}{l}\text { Tennessee Code Annotated, } \$ 36-1 \text { Adoption } \\
(2017)\end{array}$ & $x$ & $\mathscr{V}$ & $x$ \\
\hline Utah & $\begin{array}{l}\text { Utah Code Annotated, } \$ 62 \text { A4a Child Welfare } \\
\text { Services }(2017)\end{array}$ & $x$ & $\mathscr{V}$ & $x$ \\
\hline \multirow[t]{2}{*}{ Vermont } & $\begin{array}{l}\text { Adoption Act, Vermont Statutes Annotated, Title } \\
\text { 15A (2017) }\end{array}$ & $x$ & $\mathscr{V}$ & $x$ \\
\hline & $\begin{array}{l}\text { Vermont Statutes Annotated, Title 33: Human } \\
\text { Services, } \$ \$ \text { 51-53 Juvenile Proceedings }\end{array}$ & & & \\
\hline
\end{tabular}


Table 1. State-Level ICWA Provisions (continued)

\begin{tabular}{|c|c|c|c|c|}
\hline Jurisdiction & $\begin{array}{l}\text { Name of law }(s) / \text { section of state statute with } \\
\text { provisions for Indigenous children }\end{array}$ & $\begin{array}{l}\text { State version of } \\
\text { ICWA }\end{array}$ & Cites ICWA & Tribal authority \\
\hline \multirow[t]{2}{*}{ Washington } & $\begin{array}{l}\text { Washington Revised Code, SS 13.34 Dependency } \\
\text { and Termination of Parent-Child Relationship; } \\
\text { 13.36 Guardianship; } 26.10 \text { Non-Parental Action } \\
\text { for Child Custody; } 26.33 \text { Adoption; } 74.13 \text { Child } \\
\text { Welfare Service (2017) }\end{array}$ & $\sqrt{ }$ & $\mathscr{N}$ & 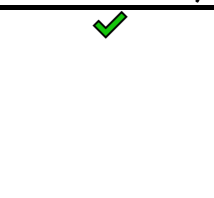 \\
\hline & $\begin{array}{l}\text { Washington State Indian Child Welfare Act, } \\
\text { Revised Code of Washington, } \$ 13.38 .010 \text { et seq. } \\
(2017)\end{array}$ & & & \\
\hline \multirow[t]{2}{*}{ Wisconsin } & $\begin{array}{l}\text { Uniform Child Custody Jurisdiction and } \\
\text { Enforcement Act, Wisconsin Statutes, } \$ 822 \\
(2018)\end{array}$ & $\mathscr{V}$ & $\mathscr{V}$ & $\mathscr{N}$ \\
\hline & $\begin{array}{l}\text { Wisconsin Statutes, } \$ 938 \text { Juvenile Justice Code } \\
(2018)\end{array}$ & & & \\
\hline Wyoming & $\begin{array}{l}\text { Child Protection Act, Wyoming Statutes, } \mathbb{\$} 14-3 \text { - } \\
412(2018)\end{array}$ & $x$ & $\mathscr{V}$ & $x$ \\
\hline
\end{tabular}

Table 2 shows forms of adoption protections for Indigenous children in the U.S. by state. It indicates: (a) Rights and responsibilities of Indian parents: These include consent to adoption procedures specific to Indian children, including withdrawal of consent to adoption; duty of parents to disclose Indigenous heritage for the purposes of determining applicability of ICWA; and termination of parental rights and procedures. (b) Cultural protections: These include provisions for culturally appropriate services; provisions to maintain cultural connections, kinship care, customary care, or custom adoption; and postadoption agreements.(c) Administrative concerns: These include reference to ICWA provisions for interstate placement; agreements between state social services directors and tribes; mention of state responsibility for ICWA compliance; provisions on information collection, access to records, confidentiality, and disclosure of records; specific funds for adoption; and ICWA grants. (d) Provisions from the 2015 ICWA Federal Guidelines: Specifically, this section indicates whether the state statutes include provisions pertaining to the "active efforts" standard and qualified expert witness requirement. 
Table 2. State Forms of Adoption Protections for Indigenous Children in the United States

\begin{tabular}{|c|c|c|c|c|}
\hline Jurisdiction & $\begin{array}{c}\text { Rights and } \\
\text { responsibilities of } \\
\text { Indigenous parents }\end{array}$ & Cultural protections & $\begin{array}{c}\text { Administrative } \\
\text { concerns }\end{array}$ & $\begin{array}{l}\text { Provisions mirrored } \\
\text { in the } 2016 \\
\text { guidelines }\end{array}$ \\
\hline Alabama & $\times$ & $\checkmark$ & $x$ & $\times$ \\
\hline Alaska & $\mathscr{V}$ & $x$ & $x$ & $x$ \\
\hline Arizona & $\times$ & $x$ & $x$ & $\times$ \\
\hline California & $x$ & $\mathscr{q}$ & $\mathscr{q}$ & $\times$ \\
\hline Colorado & $x$ & $x$ & $\mathscr{q}$ & $x$ \\
\hline Delaware & $x$ & $x$ & $\mathscr{q}$ & $x$ \\
\hline Florida & $x$ & $x$ & $\mathscr{V}$ & $x$ \\
\hline Idaho & $x$ & $x$ & $x$ & $x$ \\
\hline Indiana & $x$ & $x$ & $x$ & $x$ \\
\hline Iowa & $\mathscr{V}$ & $\mathscr{q}$ & $\mathscr{V}$ & $\mathscr{V}$ \\
\hline Kansas & $x$ & $\mathscr{q}$ & $x$ & $x$ \\
\hline Louisiana & $x$ & $x$ & $\mathscr{q}$ & $\times$ \\
\hline Maine & $x$ & $\mathscr{V}$ & $\mathscr{V}$ & $x$ \\
\hline Michigan & $\mathscr{V}$ & $\mathscr{V}$ & $\mathscr{V}$ & $\mathscr{V}$ \\
\hline Minnesota & $x$ & $\mathscr{q}$ & $\mathscr{V}$ & $\mathscr{q}$ \\
\hline Mississippi & $x$ & $x$ & $x$ & $x$ \\
\hline Missouri & $x$ & $x$ & $x$ & $x$ \\
\hline Montana & $\mathscr{q}$ & $x$ & $\mathscr{V}$ & $\mathscr{q}$ \\
\hline Nebraska & $\mathscr{V}$ & $\mathscr{V}$ & $\mathscr{V}$ & $\mathscr{V}$ \\
\hline New Mexico & $\mathscr{q}$ & $\mathscr{q}$ & $\mathscr{V}$ & $\times$ \\
\hline Nevada & $x$ & $x$ & $x$ & $x$ \\
\hline North Carolina & $\mathscr{q}$ & $x$ & $x$ & $x$ \\
\hline North Dakota & $x$ & $x$ & $x$ & $\mathscr{V}$ \\
\hline Oklahoma & $x$ & $\mathscr{V}$ & $\mathscr{V}$ & $x$ \\
\hline Oregon & $\mathscr{q}$ & $\mathscr{q}$ & $\mathscr{q}$ & $\mathscr{V}$ \\
\hline South Carolina & $x$ & $x$ & $x$ & $x$ \\
\hline South Dakota & $x$ & $x$ & $\mathscr{q}$ & $x$ \\
\hline Tennessee & $\times$ & $x$ & $\mathscr{q}$ & $x$ \\
\hline Utah & $x$ & $x$ & $x$ & $x$ \\
\hline Vermont & $\mathscr{q}$ & $x$ & $x$ & $x$ \\
\hline Washington & $\mathscr{V}$ & $\mathscr{q}$ & $\mathscr{V}$ & $\mathscr{q}$ \\
\hline Wisconsin & $\mathscr{q}$ & $x$ & $\mathscr{V}$ & $\mathscr{q}$ \\
\hline Wyoming & $\times$ & $x$ & $x$ & $x$ \\
\hline
\end{tabular}


Together, the tables demonstrate a broad scope of state Indigenous child welfare protections pertaining to adoption. These protections generally complement and bolster federal ICWA provisions. For instance, including ICWA-related provisions in state legal codes can help guard against the EIF defence (Fort, 2012). Moreover, state laws can provide mandates for states "to properly educate caseworkers regarding the correct application of ICWA standards" as they directly transfer some of the responsibility for ICWA compliance from the federal government to state governments (Kern, 2009, p. 51). Importantly, states' support of efforts by tribes and other Indigenous organizations to enshrine Indigenous child welfare provisions into state law often enhances the effectiveness of federal laws. The success of this approach in the context of California's custom adoption law speaks to the potency of state level laws to undergird reconciliation and legal innovation (Administrative Office of the Courts, 2013).

While state laws hold promise for alleviating some of the challenges of implementing the ICWA, certain challenges still remain. In at least one case (In re J. L., 2009), courts have struck down state Indigenous child welfare provisions for going too far in granting exceptional status to Indigenous children and families (Fort, 2012). Additionally, even in states with enhanced welfare protections for Indigenous children, fully implementing Indigenous child welfare provisions can prove challenging. For example, although California has incorporated the federal ICWA directly into its Family Code, a 2017 task force found that "neither the letter nor the spirit of the law [of federal ICWA or the Cal-ICWA] has been fully implemented" (ICWA Compliance Task Force, 2017, p. v). This finding is particularly significant, given that a large proportion of recognized Native American tribes are in California and that California is home to the most Native American-identified individuals of any state (ICWA Compliance Task Force, 2017, p. 30). Issues pertaining to enforcement of the ICWA at the federal level, such as lack of awareness regarding Indigenous child welfare provisions and inadequate funding, also hamper the efficacy of Indigenous child welfare legislation at the state level.

\section{Discussion and Policy Recommendations}

The decades-long history of the ICWA has been cited in discussion advocating federal child welfare legislation in Canada (Tasker, 2018). With the recent passage of the Act Respecting First Nations, Inuit and Métis Children, Youth and Families (Bill C-92, 2019), Canada embarks on a new era in Indigenous child welfare. Several lessons learned from the experience with the ICWA (1978) in the United States may be helpful as Canada moves towards implementation of the federal legislation. As is the case with all complex legislation, the approach to implementation of the new federal legislation will evolve over time, and the legislation itself may be amended as it is implemented. Accordingly, in applying the lessons learned from our examination of ICWA, we also reference earlier proposals put forward by academics and advocates for Indigenous rights (e.g., Grammond, 2018). In so doing, we seek to help keep the conversation about alternate and additional proposals alive in the hopes of supporting ongoing critical evaluation of and innovation in the approach to Indigenous child welfare in Canada.

Given the long history and rich context of legislative protections for Indigenous child welfare in the U.S., there are many lessons that may be helpful to consider in Canada. However, any application of these lessons to the Canadian context must be grounded in an understanding of the differences between Bill C-92 and the ICWA. Though the two pieces of legislation share a similar purpose, the ICWA is a more ambitious and comprehensive piece of legislation, implemented in a more complex policy context than 
Bill C-92. Important differences shape the ways federal Indigenous child welfare legislation can be implemented in these two countries:

- While the passage of the Act Respecting First Nations, Inuit and Métis Children, Youth and Families marks Canada's first piece of federal Indigenous child welfare legislation, over the decades, the United States has adopted several federal child welfare laws, some of which have enhanced and others which have inhibited effective implementation of the ICWA.

- Bill C-92 will be implemented in a Canadian context in which there is no tribal court system; this contrasts strongly with the U.S. situation in which the ICWA provides for jurisdiction of tribal courts over child welfare proceedings involving an Indigenous child (ICWA, 1978, $\$ 1911$; see also Borrows, 2005).

- Bill C-92 limits the application of Indigenous laws, excluding situations in which "if the application of the provision would be contrary to the best interests of the child" (Bill C-92, $2019, \$ 23)$. This contrasts with the ICWA's consistent affirmation of tribal sovereignty.

- Standards for keeping Indigenous children in their families are different in the two pieces of legislation: Bill C-92 (2019) has a "reasonable efforts" standard (\$15.1), whereas the ICWA (1978) requires heightened "active efforts" to preserve the Indian family ( $\$ 1912 \mathrm{~d})$.

- Bill C-92 does not make any provision for the delivery of stable and equitable child and family services funding. In contrast, the ICWA (1978) does provide some limited funding for tribes and other Indian organizations "to establish and operate off-reservation Indian child and family service programs” (\$ 1932).

Despite these important differences, several lessons from implementation of the ICWA do seem applicable to Bill C-92. We discuss four key lessons, which we find important for federal child welfare legislation. These lessons relate to: (a) notifying Indigenous communities of children involved with child welfare, (b) formally protecting Indigenous self-determination, (c) the importance of promoting and monitoring compliance mechanisms, and (d) the crucial role of states, provinces, and territories in reinforcing federal legislation.

\section{Community Notification is Essential}

Notifying a child's Indigenous community of any child welfare proceedings is an important element of federal Indigenous child welfare legislation, but careful attention to implementation and enforcement is required to ensure notification routinely occurs. The ICWA (1978) contains several key provisions which refer to the importance of a child's tribe being notified and included in child welfare proceedings ( $\$ \$ 1911,1912)$. However, review of ICWA implementation demonstrates many enforcement issues regarding tribal notification and participation. Inadequate funding, administrative and geographic barriers, and lack of awareness of the ICWA, have all hampered full application of provisions for tribal notification in the United States (ICWA Compliance Task Force, 2017).

Similar to the ICWA, the recently passed legislation in Canada specifically includes the rights of a child's family member and Indigenous governing body to have their views and preferences considered in decisions affecting them (Bill C-92, 2019, \$\$ 3b-c). The Act additionally notes the right of a child's family and Indigenous governing body to make representations in the case of a civil proceeding arising related to child and family services involvement ( $\$ \$ 13 \mathrm{a}-\mathrm{b})$. In order for the new legislative provisions to 
be meaningfully implemented in Canada, there is a need for greater attention to administration and enforcement. For example, Grammond (2018) suggested the federal government in Canada ought to provide equitable funding that accounts for factors like geographic location and size of the band or Indigenous authority, and that takes into consideration how these factors affect the responsiveness of the organizations (Grammond, 2018). Further revision of the new Canadian legislation could explicitly provide adequate funding for education and administration to create a mandate for federal oversight and provincial- or territorial-level compliance. This could ensure tribal involvement when Indigenous children are involved with child welfare proceedings.

\section{Indigenous Self-Determination Must be Formally Protected}

Indigenous communities' jurisdiction over child welfare-related proceedings-and clear, legally binding mechanisms for operationalizing that jurisdiction - is an important element for effective federal Indigenous child welfare legislation. The ICWA (1978) recognizes tribal jurisdiction over child custody proceedings affecting children within Indigenous communities $(\$ 1911)$ to "protect the best interests of Indian children and to promote the stability and security of Indian tribes and families” (\$1903). The lack of tribal courts in Canadian contexts significantly limits the extent to which Indigenous jurisdiction may be exercised in Canada.

An additional way in which the ICWA (1978) attempts to ensure that the interests and expertise of tribes and Indigenous organizations inform the determination of the best interests of an Indigenous child is through recognizing expert witnesses $(\$ 1912(\mathrm{f}))$. Under the ICWA guidelines, a qualified expert witness, in descending order of preference, is (1) someone knowledgeable about the customs or cultural standards of the child's tribe [band], (2) someone knowledgeable about an issue pertinent to the case (e.g., in cases involving sexual abuse, an expert on child sexual abuse), or (3) someone knowledgeable about the child (Bureau of Indian Affairs, 2016b). Ideally, the qualified expert witness would be an "expert" in the eyes of the relevant band or Indigenous organization, such as a respected Elder in the child's Indigenous community (Wakeham, 2015). Tribal court jurisdiction being the context in which these "expert witnesses" are determined and heard reinforces acknowledgment of the importance of centering Indigenous communities within child welfare proceedings in the United States.

The new Canadian legislation affirms the rights of Indigenous self-determination and self-government, including in areas related to child and family services (e.g., Bill C-92, 2019, Preamble, $\$ 18(1-2)$ ) and notes that it should be interpreted according to the best interests of the child ( $S \$ 9(1), 12(1)$ ). Further, the Act recognizes that the interests of Indigenous Peoples and Indigenous children are often aligned, providing for Indigenous customs and practices to prevail when a conflict exists between these practices and provincial or territorial laws. However, this provision applies only when there is a child welfare coordination agreement between an Indigenous governing body and the provincial government (Metallic, Friedland, Morales, Heitt, \& Craft, 2019). In addition, the absence of a tribal court system in Canada limits the possibilities for self-governance and self-determination. Further, the rights of selfdetermination in Bill C-92 only apply if the Indigenous custom or practice is in keeping with the "best interests of the child," a concept that is difficult to capture in legalistic language of broad federal legislation. Accordingly, ultimate decision-making power lies in the hands of non-Indigenous courts (Metallic, Friedland, Morales, Heitt, \& Craft, 2019), which have historically interpreted the best interest of the child standard as being at odds with the interests of Indigenous Peoples (e.g., Wakeham, 2015). 
The International Indigenous Policy Journal Vol. 11, Iss. 3

Indeed, advocates in Canada have recently argued that federal legislation should incorporate consideration of the rights and interests of a child's band or Indigenous authority in determining the placement that meets the child's best interests (Grammond, 2018; Wakeham, 2015). While language in the ICWA (1978) emphasizes the importance of supporting children's best interests in order to preserve Indian tribes and families ( SS 1901-1903), it does not explicitly mention the collective best interests of Indigenous groups. Incorporation of this concept into federal Canadian legislation would go beyond the lessons learned from the ICWA and set a higher standard for recognizing Indigenous communities' wellbeing as a worthy goal for legislation as well.

\section{Mechanisms for Promoting and Monitoring Compliance with Legislation are Necessary}

Strong guidelines and practices, along with concomitant funding, are crucial for the successful implementation of federal Indigenous child welfare legislation. The United States continues to struggle to ensure uniform implementation and compliance with the ICWA across states (Casey Family Programs, 2015), which has led to difficulty detecting and correcting incompliance with the law (Kern, 2009). The new Canadian legislation provides for coordination agreements-among the minister, the provincial governments, and Indigenous governing bodies - which could improve coordination among governments and, by extension, enhance compliance (Bill C-92, 2019, \$ 20). However, aside from articulating that a federal minister should undertake a review of the statute every five years $(\$ 31)$, there is not a provision for a federal body to monitor compliance with the law. The Bill falls short of Grammond's (2018) recent call for "[a]n independent, adequately resourced Commissioner" joined by "the government and the FNCFCS [First Nations Child and Family Caring Society]" to support and ensure compliance with Indigenous federal child welfare legislation (p. 150). Likewise, the creation of such legislation in Canada would allow for the standardization of child welfare proceedings across provincial and territorial jurisdictions. Such compliance provisions would hold the federal government accountable, one of the most serious shortcomings of the ICWA in the United States.

Funding to support full and proper implementation of Indigenous federal child welfare legislation, including monitoring and compliance, is essential. Challenges in ICWA implementation demonstrate the importance of sufficient, stable, and comprehensive funding. Adequate funding to enforce federal legislation would cover educating child welfare agencies, judges, lawyers, and community members about the details and implications of the new legislation. It would also include stable funding for development of guidelines for implementation of the legislation and for monitoring compliance. It would further require notification and engagement of Indigenous communities in child welfare proceedings. It is unclear what resources might be available to support the new Bill C-92 in Canada as it currently does not include language providing for funding to support its implementation. Addition of a funding provision in Bill C-92 would considerably bolster its potential for meaningful implementation.

\section{States, Provinces, and Territories Must Reinforce Federal Legislation}

Non-federal jurisdictional bodies (i.e., states, provinces, or territories) can bolster Indigenous child welfare legislation at the federal level. The U.S. experience with the ICWA demonstrates that a federalist system of government provides opportunity for state governments to expand and strengthen the protections of federal legislation. As examined above, in the U.S. context, state statutes pertaining to Indigenous child welfare appear to bolster federal ICWA protections through reinforcing and clarifying 
federal provisions (Fort, 2012; Kern, 2009). The Canadian legislation notes briefly the potential for provincial governments to participate, along with Indigenous governing bodies, in periodic review of the Act (Bill C-92, 2019, \$ 31(2)), and there is additional brief mention of the possibility of provincial governments to have input into transitional aspects of the Act being implemented $(\$ 34(2))$. However, it does not fully address the role of existing provincial legislation aimed at protecting Indigenous children.

Provincial and territorial governments in Canada can build on the federal legislation in order to draft statutes that more specifically address the distinct characteristics and needs of local Indigenous communities. Further development of the new federal law in Canada might provide language intended to support enshrining local Indigenous practices and customs directly in provincial and territorial codes. Every Canadian province or territory, including Prince Edward Island as of June of 2019 (Child Protection Act, 1988), has passed child welfare laws with some specific provisions for Indigenous children (Hahn \& Sinha, 2018). These provisions, which vary widely in scope, illustrate the potential for improving Indigenous child welfare through complementary legislative responses from the federal and provincial or territorial governments. Though the new Canadian legislation marks an important step in improving Indigenous child welfare in Canada, it need not preclude innovation at the provincial and territorial levels.

As demonstrated by the U.S. context, effectively implementing and enforcing Indigenous child welfare legislation requires the harmonization of three levels of government: tribal or band, territorial or provincial, and federal. As state-level Indigenous child welfare provisions have generally enhanced ICWA enforcement and compliance in the U.S., further study of and engagement with existing provincial and territorial provisions for Indigenous children in Canada may serve to support child welfare protections in the new Canadian legislation.

\section{Conclusion}

As Canada moves towards implementing the newly passed federal Bill C-92 (2019), An Act Respecting First Nations, Inuit and Métis Children, Youth and Families, lessons from implementation of the ICWA (1978) in the U.S. may prove useful. Though the ICWA, bolstered by other key elements of the U.S. policy landscape, is stronger and more far reaching than the new Canadian legislation, many of the ICWA provisions mirror those advanced by child welfare advocates and policy analysts in Canada (e.g., First Nations Child and Family Caring Society [FNCFCS], 2019; Grammond, 2018). Canadian policy makers can also learn from the ICWA's shortcomings, namely the lack of comprehensive access to services, inadequate funding, and a need for greater respect for Indigenous sovereignty and selfdetermination. As emphasized by the FNCFCS (2019), "[a]bsent affirmation of, and funding for, First Nations legal systems and courts, it appears mainstream courts will interpret the Act," resulting in nonIndigenous definitions of terms such as the "best interests" of Indigenous children (p. 3). Bill C-92's failure to affirm Indigenous Peoples' jurisdiction over laws affecting their children and communities, coupled with the lack of a direct funding stream to these communities, raises serious concerns regarding the efficacy and ethics of the federal Canadian legislation (FNCFCS, 2019).

Though the recently passed Bill C-92 in Canada contains some promising provisions, it also has shortcomings regarding compliance and enforcement. Drawing from the United States context, turning 
to provincial and territorial legislation may help address some of these concerns. True reconciliation, as articulated in Canada's TRC report (2015b), would require the divestment of power, resources, and control from mainstream child protection bodies to create space for Indigenous communities' selfdetermination. Although the new federal Canadian legislation marks a step in a possibly more meaningful direction, it fails to fully embody these reconciliation principles. In general, Indigenous child welfare protections passed by U.S. states appear to bolster the federal ICWA's protections in that context. As such, development of complementary provincial and territorial legislation may further enhance the efficacy of federal Indigenous child welfare in Canada. Such efforts may support a process of reconciliation that not only honours the inherent sovereignty and dignity of Indigenous Peoples, but also provides for the security and wellbeing of all people living in Canada.

Our discussion here is an initial attempt to analyze the ICWA in the United States with the goal of understanding how its implementation over 40 years might inform implementation of the nascent Bill C-92 in Canada. Our approach is limited in part due to the broad scope of possible implications related to the ICWA for child welfare legislation, only some of which we have attempted to address in this piece. We have narrowed our focus to the implications for Canada in particular domains (e.g., adoption) to enable more granular analysis. We hope that this piece can prompt further research aimed at bolstering implementation of Bill C-92 in ways that are meaningful for Indigenous communities across Canada. For example, looking further at conceptualization of national sovereignty in international adoption practices might indicate gaps in full acknowledgment of Indigenous communities' self-determination in Canada. Our writing soon after the passage of Bill C-92, before it has been meaningfully implemented, is a further limitation. It is our hope that this discussion will be part of ongoing attempts to understand the implications of legislative decisions and practices for Indigenous children and communities.

\section{References}

Administrative Office of the Courts. (2013). Judicial branch report to the legislature: Tribal customary adoption. Judicial Council of California. https://www.courts.ca.gov/documents/lr-TribalCustomary-Adoption-Report_123112.pdf

Administrative Organization Act of 1968, Colorado Revised Statutes $\$ \$ 24-60-1803$ (2017). https://leg.colorado.gov/sites/default/files/images/olls/crs2017-title-24.pdf

Adoption Act, New Mexico Statutes, $\$ S$ 32A-5 (2018). https://law.justia.com/codes/newmexico/2018/chapter-32a/article-5/

Adoption Act, 15A Vermont Statutes Annotated, SS 15A (2017). https://legislature.vermont.gov/ statutes/title/15A

Adoption and Safe Families Act of 1997, 42 U.S.C. 1305 (1997). https://www.congress.gov/105/ plaws/publ89/PLAW-105publ89.pdf

Adoptive Couple v. Baby Girl, 570 U.S. 637 (2013). https://supreme.justia.com/cases/federal/us/ $\underline{570 / 637 /}$ 
Alabama Code, Title 12. Courts, $\$ 12-15-314$ (2016). https://codes.findlaw.com/al/title-12-courts/alcode-sect-12-15-314.html

Alaska Statutes, Title 25: Marital and Domestic Relations, $\$$ 25.23.060 Execution of Consent; Consent as Power of Attorney (2008). http://www.touchngo.com/lglcntr/akstats/Statutes/ title25/Chapter23/Section060.htm

Arizona Revised Statutes, Title 8: Child Safety, SS 8-105.01, 8-106, 8-515.05, 8-535 (2018). https: //www.azleg.gov/arsDetail/?title $=8$

Assembly of First Nations. (2019, June 20). AFN National Chief Bellegarde says newly passed legislation will help build stronger and healthier First Nations [Press release]. https://www.afn.ca/afn-national-chief-bellegarde-says-newly-passed-legislation-will-help-buildstronger-and-healthier-first-nations/

Baby Boy C.v Tohono O'odham Nation, (2005), NY Slip Op 09260. https://law.justia.com/cases/ new-york/appellate-division-first-department/2005/2005-09259.html

Bagley, C. (1991). Adoption of Native children in Canada: A policy analysis and a research report. In H. Altstein \& R. J. Simon (Eds.), Intercountry adoption: A multinational perspective (pp. 55-79). Praeger Publishers. https://doi.org/10.1093/sf/70.2.565

Bill C-92, An Act Respecting First Nations, Inuit and Métis Children, Youth and Families, S.C. 2019, c. 24. https://www.canlii.org/en/ca/laws/astat/sc-2019-c-24/152135/sc-2019-c-24.html

Borrows, J. (2005). Indigenous legal traditions in Canada. Washington University Journal of Law, 19, 167-220. https: //openscholarship.wustl.edu/cgi/viewcontent.cgi?article=1380\&context= law journal_law policy

Bryce, P. H. (1907). Report on the Indian schools of Manitoba and the North-West Territories. Government Printing Bureau. http://peel.library.ualberta.ca/bibliography/3024.html

Bureau of Indian Affairs. (2016a). Guidelines for implementing the Indian Child Welfare Act. https://www.bia.gov/sites/bia.gov/files/assets/bia/ois/pdf/idc2-056831.pdf

Bureau of Indian Affairs. (2016b). Indian Child Welfare Act proceedings. http://www.federalregister.gov/documents/2016/06/14/2016-13686/indian-child-welfareact-proceedings

California Family Code, S\$ 170-185 Indian Children. https://leginfo.legislature.ca.gov/ faces/codedisplayexpand.xhtml?tocCode=FAM

California Probate Code, SS 1449, 1459, 1460.2, 1500.1. https://leginfo.legislature.ca.gov/faces/ codesTOCSelected.xhtml? tocCode $=$ PROB \& tocTitle $=+$ Probate + Code +-+ PROB 
California Welfare and Institutions Code, \$\$ 360-371. https://leginfo.legislature.ca.gov/faces/ codes displayText.xhtml lawCode $=$ WIC \&division $=2 . \&$ title $=\&$ part $=1 . \&$ chapter $=2 . \&$ article $=1$ $\underline{0 .}$

Carrière, J. (2008). Maintaining identities: The soul work of adoption and Aboriginal children. Pimatisiwin: A Journal of Indigenous and Aboriginal Community Health, 6(1), 61-80. https://journalindigenouswellbeing.com/media/2018/10/4_Carriere.pdf

Carrière, J. (2010). Maintaining identities: The soul work of adoption and Aboriginal children. In J. Carrière (Ed.), AskiAwasis/Children of the Earth: First Peoples speaking on adoption (pp.1215). Fernwood Publishing.

Casey Family Programs. (2015). A research and practice brief: Measuring compliance with the Indian Child Welfare Act. http://www.casey.org/media/measuring-compliance-icwa.pdf

Catawba Indian Claims Settlement Act, South Carolina Code of Laws Annotated, $\$ 27-16-80$. https://www.scstatehouse.gov/code/t27c016.php

Child Protection Act, RSPEI 1988, c C-5.1. https://www.canlii.org/en/pe/laws/stat/rspei-1988-c-c5.1/latest/rspei-1988-c-c-5.1.html

Child Protection Act, Wyoming Statutes, $\$$ 14-3-412 (2018). https://law.justia.com/codes/ wyoming/2018/title-14/chapter-3/article-4/section-14-3-412/

Child Welfare Information Gateway. (2019). Major federal legislation concerned with child protection, child welfare, and adoption. U.S. Department of Health and Human Services, Children's Bureau.

Children and Families Administration. (2018, March 15). Adoption and Foster Care Analysis and Reporting System: Advance notice of proposed rulemaking (RIN: 0970-AC72). https://www.federalregister.gov/documents/2018/03/15/2018-05042/adoption-and-fostercare-analysis-and-reporting-system

Children's Bureau. (2009). Considerations for Indian tribes, Indian tribal organizations or tribal consortia seeking to operate a tribal Title IV-E program. U.S. Department of Health and Human Services. http://www.acf.hhs.gov/sites/default/files/cb/tribal_considerations.pdf

Children's Code, New Mexico Statutes, $\$ \$$ 32A-1-8, 32-1-14 (2018). https://law.justia.com/ codes/new-mexico/2018/chapter-32a/

Colorado Children’s Code, Colorado Revised Statutes, \$ 19-1-126 (2017). https://leg.colorado.gov/sites/default/files/images/olls/crs2017-title-19.pdf

De Facto Custodian Act, Idaho Statutes, $\$ 32-17-1701$ (2017). https://legislature.idaho.gov/ statutesrules/idstat/Title32/T32CH17/ 
Delaware Annotated Code, Title 31: Welfare, S\$ 381-382 Interstate Compact for the Placement of Children. https://delcode.delaware.gov/title31/c003/sc06/index.shtml

di Tomasso, L., \& de Finney, S. (2015). A discussion paper on Indigenous custom adoption, Part 1: Severed connections-Historical overview of Indigenous adoption in Canada. First Peoples Child \& Family Review, 10(1), 7-18.

Family First Prevention Services Act of 2018, 115 P.L. 123, 132 Stat. 64, 2018 Enacted H.R. 1892, 115 Enacted H.R. 1892, SS 50701-50782.

First Nations Child and Family Caring Society (FNCFCS). (2019, March 9). Preliminary briefing sheet: Bill C-92, An Act Respecting First Nations, Métis and Inuit Children, Youth and Families. https://fncaringsociety.com/sites/default/files/legislation bn_march 9 2019.pdf

First Nations chiefs call for protests to oppose Indigenous child welfare bill. (2019, May 28). CBC News. https://www.cbc.ca/news/canada/edmonton/bill-c-92-first-nations-alberta-edmonton$\underline{1.5127025}$

Florida Statutes, Title 30: Social Welfare, SS 30-409 (2018). http://www.leg.state.fl.us/statutes/ index.cfm?App mode=Display Statute\&URL=0400-0499/0409/0409ContentsIndex.html \&StatuteYear=2018\&Title=\%2D\%3E2019\%2D\%3EChapter\%20409

Fluke, J., Harden, B. J., Jenkins, M., \& Ruehrdanz, A. (2011, December). Research synthesis on child welfare: Disproportionality and disparities. In Disparities and disproportionality in child welfare: An analysis of the research (pp. 1-93; Papers from a Research Symposium Convened by the Center for the Study of Social Policy and the Annie A. Casey Foundation on behalf of the Alliance for Racial Equity in Child Welfare). https://repositories.lib.utexas.edu/bitstream/ handle $/ 2152 / 15376 /$ casey disparities childwelfare.pdf? sequence $=5$

Fort, K. (2010). Comprehensive state ICWA laws. Turtle Talk. https://turtletalk.blog/icwa/ comprehensive-state-icwa-laws/

Fort, K. E. (2012). Waves of education: Tribal-state court cooperation and the Indian Child Welfare Act. Tulsa Law Review, 47. https://digitalcommons.law.utulsa.edu/tlr/vol47/iss3/3/

Fostering Connections to Success and Increasing Adoptions Act of 2008, 110 P.L. 351, 122 Stat. 3949. https://www.congress.gov/110/plaws/publ351/PLAW-110publ351.pdf

Government Accountability Office. (2005). Indian Child Welfare Act: Existing information on implementation issues could be used to target guidance and assistance to states. United States Government Accountability Office. http://www.gao.gov/new.items/d05290.pdf

Graham, L. M. (2008). Reparations, self-determination, and the Seventh Generation. Harvard Human Rights Journal, 21, 47-118. https://papers.ssrn.com/sol3/papers.cfm?abstract $\underline{\mathrm{id}=1126774}$ 
Grammond, S. (2018). Federal legislation on Indigenous child welfare in Canada. Journal of Law and Social Policy, 28. http://digitalcommons.osgoode.yorku.ca/jlsp/vol28/iss1/7

Hahn, H., \& Sinha, V. (2018). Adoption protections for Indigenous children in Canada. Centre for Research on Children and Families. https://cwrp.ca/sites/default/files/publications/en/ 196e.pdf

Halibi, S. F. (2014). Abstention, parity, and Treaty Rights: How federal courts regulate jurisdiction under the Hague Convention on the Civil Aspects of International Child Abduction. Berkeley Journal of International Law, 32, 144-194. http://lawcat.berkeley.edu/record/1126170/files/ fulltext.pdf

In re J.L, 779 N.W.2d 481 (Iowa Ct. App. 2009).

Indian Affairs Bureau. (2015, February 25). Guidelines for state courts and agencies in Indian custody proceedings (10146-10159). Federal Register, 80(37). http://www.gpo.gov/fdsys/pkg/FR2015-02-25/pdf/FR-2015-02-25.pdf

ICWA Compliance Task Force. (2017). California ICWA Compliance Task Force: Report to the California Attorney General's Bureau of Children's Justice. https://theacademy.sdsu.edu/wpcontent/uploads/2015/06/icwa-compliance-task-force-final-report-2017.pdf

Indian Child Welfare Act of 1978, 25 U.S.C. \$S 1901-1963 (1978). https://uscode.house.gov/ view.xhtml?path=/prelim@title25/chapter21\&edition=prelim

Indiana Code, Title 31: Family and Juvenile Law, \$ 31-28-6-1 Interstate Compact for the Placement of Children (2017). http://iga.in.gov/legislative/laws/2017/ic/titles/031\#31-31

Iowa Indian Child Welfare Act, Iowa Code, \$ 232B.1 (2016). https://law.justia.com/codes/iowa/ 2016/title-vi/chapter-232b/section-232b.1/

Isaac, D. (2019, May 24). Debate over Bill C-92 heats up as it's pushed through the House of Commons. Nation News. http://nationnews.ca/politics/debate-over-bill-c-92-heats-up-as-its-pushedthrough-the-house-of-commons/

Jaffke, C. L. (2006). The “Existing Indian Family” exception to the Indian Child Welfare Act: The states' attempt to slaughter tribal interests in Indian Children. Louisiana Law Review, 66. https://digitalcommons.law.lsu.edu/lalrev/vol66/iss3/4/

Johnston, P. (1983). Native children and the child welfare system. Canadian Council on Social Development.

Jones, B. J., Tilden, M., \& Gaines-Stoner, K. (2008). The Indian Child Welfare Act handbook(2 ${ }^{\text {nd }}$ ed.). American Bar Association. 
Kansas Statutes Annotated, Title 38: Minors, $\$ \$ \$$ 38-220 Revised Kansas Code for Care of Children (2015). http://www.kslegislature.org/li 2016/b2015_16/statute/038 $000 \quad 0000$ chapter/038_022_0000_article/

Kern, M. L. (2009). A generation later: Reservations with the Indian Child Welfare Act. Children's Legal Rights Journal, 29.

Kinship Guardianship Act, New Mexico Statutes $\$ \$ 40-10 B(2018)$. https://law.justia.com/codes/newmexico/2018/chapter-40/article-10b/

Louisiana Revised Statutes, Louisiana Children’s Code, \$ 13-1629 (2017). https://law.justia.com/ codes/louisiana/2017/code-childrenscode/

Maine Revised Statutes Annotated, Title 22: Health and Welfare (2017). http://legislature.maine.gov/ statutes $/ 22 /$ title22ch0sec0.html

Metallic, N. W., Friedland, H., \& Morales, S. (2019). The promise and pitfalls of C-92: An Act Respecting First Nations, Inuit, and Métis Children, Youth and Families. Yellowhead Institute. https://yellowheadinstitute.org/wp-content/uploads/2019/07/the-promise-and-pitfalls-of-c92-report.pdf

Metallic, N. W., Friedland, H., Morales, S., Hewitt, J., \& Craft, A. (2019). An Act Respecting First Nations, Inuit, and Métis Children, Youth and Families: Does Bill C-92 make the grade? Yellowhead Institute. https://yellowheadinstitute.org/wp-content/uploads/2019/03/doesbill-c-92-make-the-grade -full-report.pdf

Michigan Indian Family Preservation Act, Michigan Compiled Laws, SS 712B.1-41 (2012). http://www.legislature.mi.gov/documents/2011-2012/publicact/pdf/2012-PA-0565.pdf

Milloy, J. S. (1999). A national crime: The Canadian government and the Residential School System, 1879 to 1986. University of Manitoba Press.

Minnesota Indian Family Preservation Act, Minnesota Statutes, S\$ 260.751-260.835 (2017). https://www.revisor.mn.gov/statutes/2017/cite/260

Minnesota Statutes, SS 260.851-260.93 Minnesota Interstate Compact on the Placement of Children (2017). https://www.revisor.mn.gov/statutes/2017/cite/260.851

Minnesota Statutes, $\$ 256.01$ Commissioner of Human Services; Powers, Duties (2017). https://www.revisor.mn.gov/statutes/2017/cite/256.01

Minnesota Statutes, \ 257C De Facto Custodian and Interested Third Party (2017). https://www.revisor.mn.gov/statutes/2017/cite/257C

Minnesota Statutes, $\$ 259$ Change of Name, Adoption (2017). revisor.mn.gov/statutes/2017/cite/259 
Minnesota Statutes, SS 260.01 Duty to Ensure Placement Prevention and Family Reunification; Reasonable Efforts (2017). https://www.revisor.mn.gov/statutes/2017/cite/260.012

Mississippi Band of Choctaw Indians v. Holyfield, 490 U.S. 30 (1989).

Montana Safe Haven Newborn Protection Act, Montana Code Annotated, $\$ 40-6-405$ (2019). https://leg.mt.gov/bills/mca/title 0400/chapter 0060/part 0040/sections index.html

Montana Code Annotated, Title 42: Adoption, Chapter 2: Adoption of Child, Part 6: Petition to Terminate Parental Rights, $\$$ 42-2-604 (2019). https://leg.mt.gov/bills/mca/title 0420/ chapter 0020/part 0060/section 0040/0420-0020-0060-0040.html

Montana Code Annotated, Title 52: Family Services, Chapter 2: Children’s Services, Part 1: Child Welfare Services, \$ 52-2-117 Indian Child Welfare Specialist (2019). https://leg.mt.gov/bills/ $\mathrm{mca} /$ title 0520/chapter_0020/part_0010/section_0170/0520-0020-0010-0170.html

Multiethnic Placement Act of 1994, Public Law 103-382.

National Child Welfare Resource Center for Tribes. (2014). Tribal child welfare funding findings: Overview of funding for tribal child welfare. http://www.nrc4tribes.org/Tribal-Child-WelfareFunding-Findings.cfm

National Conference of State Legislatures (NCSL). (2018). State statutes related to the Indian Child Welfare Act. http://www.ncsl.org/research/human-services/state-statutes-related-to-indianchild-welfare.aspx

National Council of Juvenile and Family Court Judges. (2009). Court reform and American Indian and Alaska Native children: Increasing protections and improving outcomes (Technical assistance brief). https://www.ncjfcj.org/publications/court-reform-and-american-indian-and-alaskannative-children/

National Council of Juvenile and Family Court Judges. (2012, August 9). The history and spirit of $I C W A$ [Video]. YouTube. https://www.youtube.com/watch?v=yAcLsvEubwE

National Council of Juvenile and Family Court Judges. (2017). Disproportionality rates for children of color in foster care (fiscal year 2015). https://www.ncjfcj.org/publications/disproportionalityrates-for-children-of-color-in-foster-care-fiscal-year-2015/

National Indian Child Welfare Association. (2015). Setting the record straight: The Indian Child Welfare Act fact sheet [Fact sheet]. https://www.nicwa.org/wpcontent/uploads/2017/04/ Setting-the-Record-Straight-ICWA-Fact-Sheet.pdf

National Indian Child Welfare Association. (2017). Report on disproportionality of placements of Indian children. https://www.nicwa.org/wp-content/uploads/2017/09/DisproportionalityTable.pdf 
Nebraska Indian Child Welfare Act, Nebraska Revised Statutes, $\$ 43-1501,43-1517$ (2015). https://nebraskalegislature.gov/laws/laws-index/chap43-full.html

Nebraska Statutes, $\$ 43-1103 Interstate Compact for the Placement of Children. https://nebraskalegislature.gov/laws/statutes.php?statute $=43-1103$

Nevada Revised Statutes, Protection of Children from Abuse and Neglect, $\$$ 432B.397 (2015). https://www.leg.state.nv.us/nrs/nrs-432b.html

Nichols, R. L. (2017). From the Sixties Scoop to Baby Veronica: Transracial adoption of Indigenous children in the USA and Canada. In M. Shackleton (Ed.), International adoption in North American literature and culture (pp. 3-26). https://doi.org/10.1007/978-3-319-59942-7

North Carolina General Statutes, SS 48 Adoptions (2017). https://www.ncleg.gov/Laws/GeneralStatuteSections/Chapter48

Oklahoma Indian Child Welfare Act, Oklahoma Statute, SS 10-40.1 to 10-40.9 (2017). http://webserver1.lsb.state.ok.us/OK_Statutes/CompleteTitles/os10.rtf

Oregon Revised Statutes, S\$ 109.309, 109.312, 109.350, 125.025, 418.627, 419A, 419B (2017). https://www.oregonlegislature.gov/bills_laws/Pages/ORSarchive.aspx

Public Law 280 of August 15, 1953, H.R. 1063, ch. 505, 67 Stat., 588 (1953). https://www.govinfo.gov/ content/pkg/STATUTE-67/pdf/STATUTE-67-Pg588.pdf\#page=1

Safe Haven for Infants Act, New Mexico Statutes, \$ 24-22 (2018). https://law.justia.com/codes/newmexico/2018/chapter-24/article-22/

Sandefur, T. (2017). Escaping the ICWA penalty box: In defense of equal protection for Indian children. Children’s Legal Rights Journal, 37(1), 6-80. https://doi.org/10.2139/ssrn.2796082

Simon, R. J., \& Hernandez, S. (2008). Native American transracial adoptees tell their stories. Lexington Books.

Sinclair, R. (2007). Identity lost and found: Lessons from the Sixties Scoop. First Peoples Child \& Family Review: A Journal on Innovation and Best Practices in Aboriginal Child Welfare Administration, Research, Policy \& Practice, 3(1), 65-82. http://fncaringsociety.com/sites/ default/files/online-journal/vol3num1/Sinclair_pp65.pdf

Sinclair, R. (2009). Identity or racism? Aboriginal transracial adoption. In R. Sinclair, M. A. Hart, \& G. Bruyere (Eds.), Wícihitowin: Aboriginal social work in Canada (pp. 89-113). Fernwood Publishing.

Sinha, V., Trocmé, N., Fallon, B., MacLaurin, B., Fast, E., Prokop, S. T., Petti, T., Kozlowski, A., Black, T., Weightman, P., Bennett, M., Formsma, J., Brascoupe, P., O’Brien, S., Flette, E., Gray, R., Lucus, L., Hoey, S., Levi, J., . . Richard, K. (2011). Kiskisik Awasisak: Remember the children: Understanding the overrepresentation of First Nations children in the child welfare system. 
Assembly of First Nations. http://www.cwrp.ca/sites/default/files/publications/en/FNCIS2008 March2012_RevisedFinal.pdf

Sinha, V., \& Wray, M. (2015). Foster care disparity for Aboriginal children in 2011 (CWRP Information Sheet \#165E). Centre for Research on Children and Families. http://cwrp.ca/sites/default/ files/publications/en/166e.pdf

South Dakota Codified Laws Annotated, \$S 25-5A, 26-7A, 26-8A (2018). https://sdlegislature.gov/ statutes/Codified_Laws/Default.aspx

Statistics Canada. (2016). Family Characteristics (22), Aboriginal Identity (9), Registered or Treaty Indian Status (3), Age (8A) and Sex (3) for the Population in Private Households of Canada, Provinces and Territories, Census Metropolitan Areas and Census Agglomerations, 2016 Census- 25\% Sample Data. [Data table]. https://www12.statcan.gc.ca/censusrecensement $/ 2016 / \mathrm{dp}$-pd $/ \mathrm{dt}$-td $/ \mathrm{Rp}$-eng.cfm?TABID=2\&Lang=E\&APATH=3\&DETAIL= $\underline{0 \& \mathrm{DIM}=0 \& \mathrm{FL}=\mathrm{A} \& \mathrm{FREE}=0 \& \mathrm{GC}=0 \& \mathrm{GID}=1341679 \& \mathrm{GK}=0 \& \mathrm{GRP}=1 \& \mathrm{PID}=110517 \& \mathrm{PRID}}$ $=10 \& \mathrm{PTYPE}=109445 \& \mathrm{~S}=0 \& \mathrm{SHOWALL}=0 \& \mathrm{SUB}=0 \& \mathrm{Temporal}=2017 \& \mathrm{THEME}=122 \& \mathrm{VID}$ $=0 \& \mathrm{VNAMEE}=\& \mathrm{VNAMEF}=\& \mathrm{D} 1=0 \& \mathrm{D} 2=0 \& \mathrm{D} 3=0 \& \mathrm{D} 4=0 \& \mathrm{D} 5=0 \& \mathrm{D} 6=0$

Subcommittee on Indian Affairs of the Committee on Interior and Insular Affairs, Senate, $93^{\text {rd }}$ Cong. (1974).

Task Force on Federal, State, and Tribal Jurisdiction. (1976). Report on federal, state, and tribal jurisdiction: Final report to the American Indian Policy Review Commission. U.S. Government Printing Office. https://narf.org/nill/documents/icwa/federal/lh/76rep/76rep.pdf

Tasker, J. P. (2018, January 25). Jane Philpott unveils 6-point plan to improve 'perverse' First Nations child welfare system. $C B C$. http://www.cbc.ca/news/politics/jane-philpott-six-point-plan-firstnations-child-welfare-1.4503264

Tennessee Code Annotated, \$ 36-1 (2017). https://law.justia.com/codes/tennessee/2017/title36/chapter-1/

Trocmé, N., Fallon, B., MacLaurin, B., Sinha, V., Black, T., Fast, E., Felstiner, C., Hélie, S., Turcotte, D., Weightman, P., Douglas, J., \& Holroyd, J. (2010). Canadian incidence study of reported child abuse and neglect 2008 (CIS-2008): Major findings. Public Health Agency of Canada. https://cwrp.ca/sites/default/files/publications/en/CIS-2008-rprt-eng.pdf

Trowbridge, S. (2017). Legal challenges to ICWA: An analysis of current case law. Child Law Practice Today, 36(1). https://www.americanbar.org/groups/public interest/child_law/resources/ child law practiceonline/child law practice/vol-36/january-2017/legal-challenges-to-icwa-an-analysis-of-current-case-law/

Truth and Reconciliation Commission of Canada (TRC). (2015a). Honouring the truth, reconciling for the future. http://www.trc.ca/assets/pdf/Honouring the Truth_Reconciling for the Future July_23 2015.pdf 
Truth and Reconciliation Commission of Canada (TRC). (2015b). Canada's residential schools: Reconciliation (The final report of the Truth and Reconciliation Commission of Canada, Volume 6). http://nctr.ca/assets/reports/Final\%20Reports/Volume 6 Reconciliation English Web.pdf

Turtle Talk. (2015). Comprehensive state ICWA laws. https://turtletalk.blog/icwa/comprehensivestate-icwa-laws/

Uniform Child Custody Jurisdiction and Enforcement Act, Idaho Statutes, \ 32-11-101 (2017). https://legislature.idaho.gov/statutesrules/idstat/Title32/T32CH11/

Uniform Child Custody Jurisdiction and Enforcement Act, Mississippi Code Annotated, \$ 93-27-104 Application to Indian Tribes (2010). https://law.justia.com/codes/mississippi/2010/title$\underline{\text { 93/27/93-27-104/ }}$

Uniform Child Custody Jurisdiction and Enforcement Act, Missouri Revised Statutes, $\$ 452.715$ Application to Indian Tribes (2009). https://revisor.mo.gov/main/OneSection.aspx?section= $\underline{452.715 \& \mathrm{bid}=25088 \& \mathrm{hl}=452.715 \% \mathrm{u} 2044}$

Uniform Child Custody Jurisdiction and Enforcement Act, North Dakota Century Code, S\$ 14-14.1, 27-20-32.3 (2017). https://www.legis.nd.gov/cencode/t14c14-1.html

Uniform Child Custody Jurisdiction and Enforcement Act, Wisconsin Statutes, $\$ 822$ (2018). https://docs.legis.wisconsin.gov/statutes/statutes/822

Uniform Juvenile Court Act, North Dakota Century Code, \$ 27-20. https://www.legis.nd.gov/ cencode/t27c20.pdf

The United States Attorney's Office District of Minnesota. (2015, May 1). Frequently asked questions about Public Law 83-280. https://www.justice.gov/usao-mn/Public-Law\%2083-280

Utah Code Annotated, \$S 62A4a (2017). https://le.utah.gov/xcode/Title62A/Chapter4A/C62A4a 1800010118000101.pdf

Vermont Statutes Annotated, Title 33: Human Services $\$ \$ 5$ 51-53 (2017). https://legislature.vermont.gov/statutes/chapter/33/051

Wahl, P. K. (2010). Little power to help Brenda? A defense of the Indian Child Welfare Act and its continued implementation in Minnesota. William Mitchell Law Review, 26(3). https://open.mitchellhamline.edu/wmlr/vol26/iss3/7/

Walkem, A. (2015). Wrapping our ways around them: Aboriginal communities and the CFCSA guidebook. Nlaka'pamux Nation Tribal Council. http://www.nntc.ca/docs/ wowat bc cfcsa 1.pdf

Washington Revised Code, $\$ S$ 13.34, 13.36, 26.10.26.33, 74.13 (2017). http://app.leg.wa.gov/RCW/ default.aspx

Published by Scholarship@Western, 2020 
Washington State Indian Child Welfare Act, Revised Code of Washington, \$ 13.38.010 et. seq. (2017). https://app.leg.wa.gov/RCW/default.aspx? cite $=13.38$

Watt, T., \& Kim, S. (2019). Race/ethnicity and foster youth outcomes: An examination of disproportionality using the national youth in transition database. Children and Youth Services Review, 102, 251-258. https://doi.org/10.1016/j.childyouth.2019.05.017

Wilson, N. D. (2007). Tribal consequences of urban Indian relocation: Case examination of the existing Indian Family Exception \& adoptive placement under the Indian Child Welfare Act. http://law.msu.edu/indigenous/papers/2007-04.pdf

Wisconsin Statutes, $\$ 938$ Juvenile Justice Code (2018). https://docs.legis.wisconsin.gov/statutes/ statutes/938

Zug, M. A. (2014). The real impact of Adoptive Couple v. Baby Girl: The existing Indian family doctrine is not affirmed, but the future of ICWA's placement preferences is jeopardized. Capital University Law Review, 42. https://papers.ssrn.com/sol3/papers.cfm?abstract id=2333797 